\title{
The Circular Economy: a Re-Emerging Industry?
}

\author{
Van den Berghe, Karel*, Dąbrowski, Marcin+, Ersoy, Aksel*, Wandl, Alexander+, van Bueren, Ellen* \\ * Department of Management in the Built Environment, Delft University of Technology, The Netherlands \\ + Department of Urbanism, Delft University of Technology, The Netherlands
}

\begin{abstract}
This paper underlines the importance of space for the transition towards the circular economy (CE). Policymakers and industry give most attention to closing material flows, largely ignoring the important spatial implications. The CE requires (re)producing and consuming as locally as possible to avoid problem displacement. This clashes with the general urban land use policy to externalize (re)manufacturing activities. This paper proposes a methodology that combines territorial and network perspectives to understand this conflict. Our results show the importance of place to foster the CE as re-emerging industry combining existing and new activities, offering insights for planning and policy.
\end{abstract}

\section{Introduction}

In this paper, we focus on the importance of space within the circular economy (CE). We do this for two reasons. First, the policy relevance: worldwide, CE is increasingly seen as one of the key strategic societal goals towards sustainable development (Ghisellini, et al., 2016), among others, by the United Nations (UN, 2018), China (Su et al., 2013), the OECD (2019) and the European Union (cf. the Green Deal, COM, 2019). In a nutshell the rationale is: "... the objective of a CE is to reduce the societal production-consumption systems' linear material and energy throughput flows by applying materials cycles, renewable and cascade-type energy flows to the linear system." (Korhonen, et al., 2018, p. 547). Secondly there is the scientific relevance. CE is based on the hierarchical ladder of R-strategies (cf. Rethink, Reduce, Reuse, Remanufacture, Recycle, Recover) (Reike et al., 2018), building upon the waste management hierarchy as developed by Lansink, a Dutch Member of Parliament, in 1979, and later introduced in EU legislation with the 2008 Waste Framework Directive, which distinguished prevention, preparing for reuse, recycling, recovery, and landfill on a preferential scale (EC, 2008; Van Ewijk \& Stegemann, 2016). This is also known as a three tier model (3R: reduce, reuse, recycle) or a five tier model (prevention, preparing for reuse, recycling, recovery, landfill) of waste hierarchy. The rule of thumb is that the higher on the Rladder, or earlier in the production-consumption system, the less resources are needed.

What is not underlined in this R-ladder, is that also the geographical aspect is important. As argued by North (2010), CE should entail striving for more localism, or 'reverse globalisation'. Localism is, however, not understood as the end of globalisation. Here we follow North (2010, p.587) that localism "[should] focus first on producing as much as possible as locally as possible, then within the shortest possible distance, with international trade only as a last resort for goods and services that really cannot be produced more locally". This resonates with the findings of Burger et al. (2019) arguing that it would be naive to consider that in a CE no regional to global exchange would occur. Indeed, also within a CE, certain regions will be expected to specialise more or less in specific CE activities. In other words, CE will remain firmly rooted in a 'regional (circular) world' (cf. Storper, 1997). Indeed, localism does not imply that everything should be produced locally, or internalized. For some products or services, it is better - from an environmental point of view at least - to keep them externalized (North, 2010).

Regarding space, it is important for spatial planners and policy-makers to understand the role of cities and regions within the global $\mathrm{CE}$, since administrative, organisational and geographical borders and boundaries are sub-global, or in most cases even sub-national. This 'mismatch' can lead to the so-called problem displacement whereby a measure taken to decrease the environmental impact in one location, can increase the one of another (Korhonen et al., 2018). In other words, an economy, and its (in)direct effects (e.g. GHG emissions, employment), is cross-border, and in general do not match with the existing organisation, institutional and geographical structures (North, 2010).

If problem displacement is to be avoided, or at least not being aggravated, it is important to understand what functions or activities today and especially in the future (will) help to do so. If current circular activities (e.g. waste 
treatment) within or close to a certain regional economy are externalized, this entails that the resulting network of flows enlarges, as the back and forth distances increase. Although this is not always underlined, networks are not weightless. The levels of carbon embedded in goods and services depend on where they are produced and how they are transported (North, 2010), an important fact to be taken into account in the transition towards the CE. In this paper, our hypothesis is that if problem displacement occurs because existing circular activities are externalized, not only the tangible distances increase, but also the intangible distances or relations increase. This consequently constrains the knowledge spillovers within local to regional network economies derived from related and unrelated variety (Frenken et al., 2007). The reason why we focus on innovation, is because the CE - if successful - will consist of high-value production-consumption cycles (Ghisellini et al., 2016), whereas such cycles in today's systems are characterized by a rapid and high quality degradation of the input and throughput of resources. Innovation is considered key in moving up on the R-ladder, in search for a CE (cf. Murray, et al., 2017). Hence, in this paper we don't focus on innovation as such, but on the role of space and its embedded networks to enable or constrain (potential) innovation. This leads to our research question: what is the role of space in the transition towards the CE?

To answer this question, this paper is structured as follows. In the next section, we first explain why in contemporary CE literature there is not much attention for the relation between space and the existing (in)tangible networks within and beyond regions. We consequently introduce the concept of 're-emerging industry' to comprehend related and unrelated variety between existing and innovative activities. After explaining our methodology, we introduce two Dutch case studies in The Hague and Amsterdam. We focus on urbanized regions, because especially within cities, first the potential related and unrelated variety is high, but second existing industrial activities are under pressure for (residential) redevelopment, threatening thus related and unrelated variety. We end this paper with a discussion and policy recommendations.

\section{The circular economy as re-emerging industry}

\section{The disconnection between locations and flows, or between city and non-city}

As argued by Wachsmuth (2012), especially within urbanized regions there is a disconnection between a combined locational and relational perspective, that can epistemological be explained historically. First, during the beginning of the 20th century, the 'Chicago School' perspective on the city became dominant. The city became seen and analysed as a social metabolism, a metaphor on biological metabolism. Hereby, the city is a self-contained system of people that by their social ties circulate, integrate and disintegrate, making it eventually possible that the city can grow. However, as Wachsmuth continues, self-containment and growth are mutually exclusive. Conceptually thus, the city became a social phenomenon without a link to nature. Secondly, during the 1960s and 1970s, an opposite shift occurred. The city became perceived as a system of metabolic material flows and stocks, but now without a link to social processes. Hereby, the urban is studied in resource consumption and environmental constraints. This shift occurred because the field of industrial ecology (IE), studying industrial material systems on large scales, became connected with the urban scale. Wolman (1965) is hereby illustrative, analysing the city as a machine of converting resources into waste. As Wachsmuth (2012) argues, in this IE perspective, environmental problems are technical problems, rather than social ones; Therefore, to improve environmental problems, cities should adopt a more technical sustainable policy, but no attention is given to socioeconomic processes that explain or can improve (cf. innovation) what explains the origin of current phenomena.

This technical 'version' of the urban metabolism dominates today the CE debates (Korhonen, et al., 2018). This implies that not only the CE is (solution-) technical oriented, but also limited by geographically focusing on urbanized regions. Focussing only on flows within urbanized regions, however, is a contradiction and can lead to 'problem displacement' (North, 2010) whereby the, mostly negative, origins or consequences of existing tangible network locations are externalized (cf. waste treatment plant). In other words, cities, and their economies, may not be seen as isolated phenomena, but should be regarded in reciprocal relation to the world beyond their (administrative) borders (Gibbs, 2018; Swyngedouw, 2006).

As recently described by Van den Berghe \& Vos (2019), taking into account problem displacement or not, leads today to two different 'discourse versions' of circular land use policy within cities. The first 'isolated' urban version, (implicitly) ignores problem displacement and sees an opportunity to foremost cherry pick the 'positive' elements (circular residential areas that are designed circularly) and to externalize the 'negative' elements (circular industrial activities, such as waste treatment plants), at least seen from an economic, living environment or 
(profitable) real estate development. The second 'relational' version calls for the safeguarding of existing circular activities within a certain urbanized region, to keep existing and future material flows as close as possible within urbanized (consuming) regions.

\section{Re-emerging industries}

From an ecological point of view, the consequences of problem displacement are arguably clear. What is also important to take into account regarding problem displacement is its effect on (potential) innovation. Innovation plays a key role in the transition of the CE, especially because we need to go beyond the today most focused upon technical innovation (PBL, 2019). The CE, and thus innovation, has to aim as high as possible on the Rladder (Ghisellini et al., 2016). The reason why the higher on the R-ladder implies a bigger chance to achieve a fully CE, is because the technical, the social and the economic become interwoven (Murray, et al., 2017). In other words, not only the 'technical' part of circular metabolic systems should be improved as close as possible, the socioeconomic related and enabling part too (Korhonen et al., 2018).

This 'finding' within CE literature, resonates with the relatedness literature in regional studies, and in specific evolutionary economic geography (EEG) (Boschma \& Frenken, 2006). Within the latter, the study of new emerging industries (Tanner, 2014; Boschma et al., 2017) stresses the importance of location. In general, the explanation of new emerging industries, or not, depends on the path dependent built up specialisation in the past (Neffke et al., 2011) and the diversity of activities (Frenken et al., 2007). As argued by Hassink et al. (2019), mostly research focussing on emerging industries, takes the position of a local firm as starting point. While this is not per se wrong, it should not simultaneously neglect the role of other local or non-local actors, institutions or assets (Yeung, 2005). Second, mostly these studies look at the past, and explain how an emerging industry has risen. However, and this is very relevant for the CE, the potential influence of the future and (circular) discourses (cf. Van den Berghe \& Vos, 2019) is of importance to understand the rising, or not, of emerging industries. The latter the more important if one deals with spatial planning today towards the future (cf. the European Union Green Deal calling for a full circular economy 2050, COM, 2019).

In this paper we add to this that it is important to underline how exactly spatial decisions taken today, can constrain the emerging industry of tomorrow. In other words, one should understand what today exists, and how current taken decisions alter the potential future emerging development paths. This resonates with Korhonen et al. (2018) that to plan the CE, one foremost needs to understand the current CE as complete as possible. Therefore, we label the CE not as an emerging industry, but as a re-emerging industry. Although this to some level is a synonym as the literature on emerging industries also stresses the locational path dependent built up processes, we hereby want to foremost stress the importance of existing circular activities and also their locations. If the role of existing activities for the CE today is neglected (cf. PBL, 2019), and the role of their locations is not understood today, there is a potential that today taken land use measurements - even if they aim for CE -, can constrain the future innovative localides CE (cf. localism) that will innovate from existing circular activities, their locations and their embedded tangible and intangible networks.

\section{Methodology}

To comprehend the CE as re-emerging industry, we need thus to comprehend the activities existing within a certain region, and how they are embedded or not within different sorts of (un)related networks, eventually to understand how these reciprocally constitute activities (cf. Paasi, 2010). The relational approach is able to bridge this network and locational aspect. The relational approach has gained track within economic geography during the last two decades (Bathelt \& Glückler, 2003; Harrison et al., 2019; Varró \& Lagendijk, 2013). As defined by Yeung (2005, p. 48):

"a relational approach [...] seeks to identify the complex relational geometry comprising local and non-local actors, tangible and intangible assets, formal and informal institutional structures, and their interactive power relations."

The question still remains how to apply this to empirical work. For this we refer to Van den Berghe et al. (2018) wherein a methodology is proposed to conceptually bridge the territorial and network perspective in order to identify the relational geometry (Figure 1). 


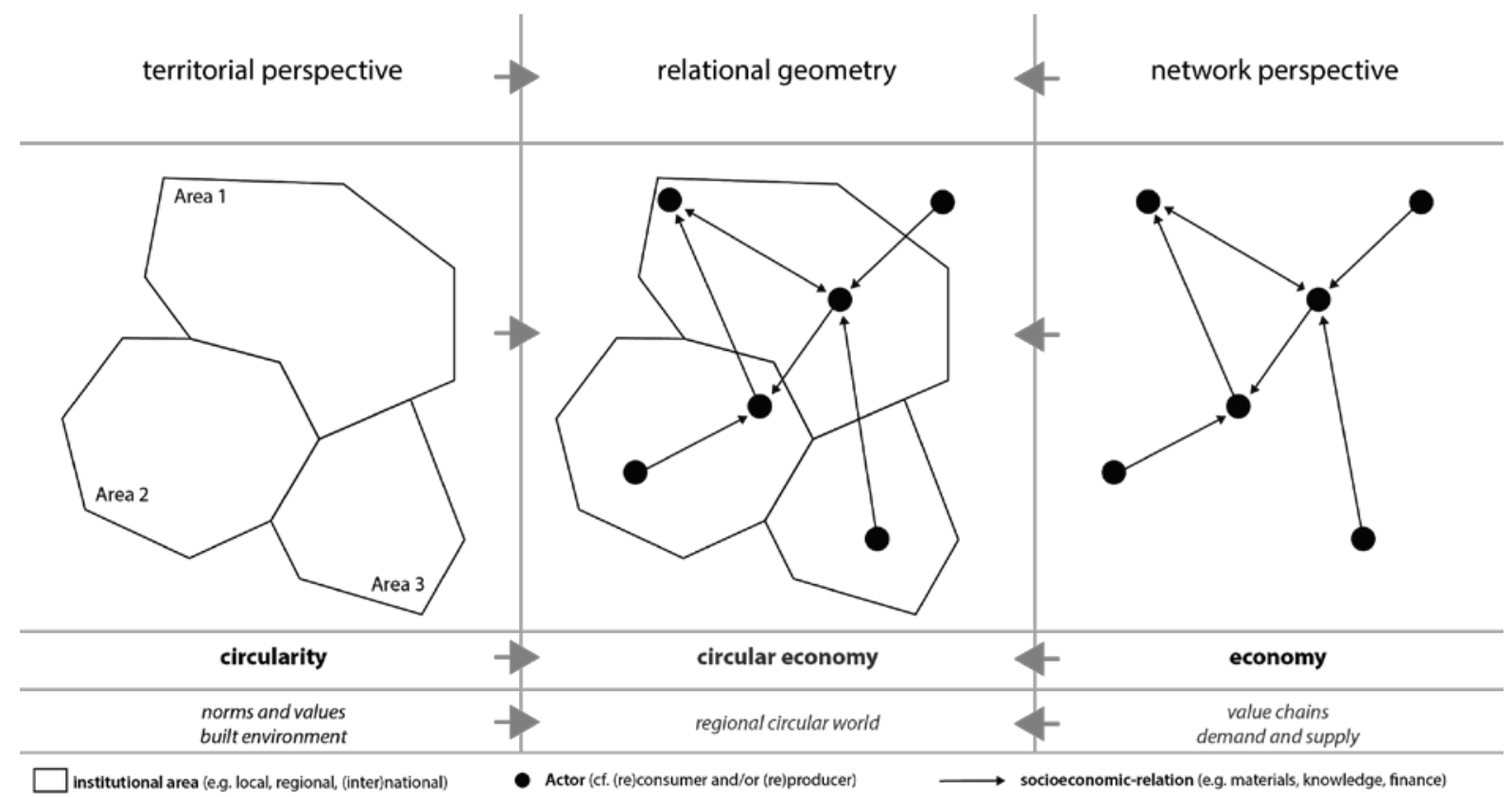

Figure 1: Conceptual framework (adapted from Van den Berghe, et al., 2018)

Our research is problem driven and does not attempt to develop theoretical generalization. Our focus is on the role of space today within the transition of the CE from tomorrow. This makes collective case study research design appropriate (Stake, 1995). A collective case study is an intrinsic case study, whereby only the case study stands central (e.g. biography), extended to several cases. This way, not the case studies per se are compared, but a common phenomenon that is been examined within these case studies, in this case the role of space.

Regarding our conceptual framework, and our aim to identify the relational geometry by bridging the territorial and network perspectives, we have chosen two case studies that are situated each on one side of this bridge. Our first case study is a case study of a locational land use conflict whereby we reflect towards the network perspective, while the second case study departs from the network perspective to then shift the attention to the territorial implications of the CE networks. The chosen research methods are adapted. The first case study is based on desktop research analysing relevant documents, verified by interviews with the stakeholders. The second case study also departs from the study of planning and policy documents for Amsterdam and its region, but its main empirical material relies on activity-based material flow analysis, developed as part of the Horizon2020 REPAiR project and applied carried out using the Geodesign Decision Support Environment software allowing for translation of data on activities related to waste into spatial data and visualisations (REPAiR, 2017a, 2017b; Arciniegas et al., 2019). The data for the analysis of waste flows came from the national LMA database on waste materials provided by the Dutch Ministry of Infrastructure and Water Management (Rijkswaterstaat, 2019) and contained all registered waste flows that were generated within the Amsterdam Metropolitan Area in the year 2016.

The activity-based material flow analysis spatially connects the LMA database with the ORBIS database (Bureau van Dijk, 2017), which provides detailed information about individual companies. The method entails assessing the volume of flows of waste, while geo-locating activities related to processing of waste materials (for more details see REPAiR, 2017b).

\section{Linking the territorial and the network perspective}

\section{The Binckhorst - a local conflict between circular area design and circular area functioning}

The Binckhorst is an industrial and commercial area within the city of The Hague, of around 150 hectares. Of this 150, 11 hectare is water. The latter is important to mention, because The Binckhorst is an industrial port area along the Trekvliet canal connecting The Hague with the port of Rotterdam. The Binckhorst' origin goes back to 
the end of the 19th century, when The Hague experienced a significant increase in population and activities (Meijers, et al., 2014). To meet the increasing energy demand, The Hague opened a new large gas driven energy plant in the then greenfield Binckhorst. The plant had to be built along the canal, because cokes needed to be imported via barges from the port of Rotterdam. During the next decades, other industrial functions (e.g. metal factory, wood factory) were built along the canal and newly built railways. Because the demand for large expansion room for industrial functions remained high, new docks were constructed within the Binckhorst along the canal. Subsequently, many other companies opened a factory within the Binckhorst, which became a heavy industrial area of large scale functions (e.g. concrete factory, car manufacturing factory, asphalt factory), accessible for maritime transport. From the 1970s onwards, many of the existing industrial functions closed which were retransformed into commercial functions, eventually making the area a mix of remaining industrial functions (e.g. asphalt factory), garages, and offices (e.g. KPN) (Albers \& Benjamins, 2012).

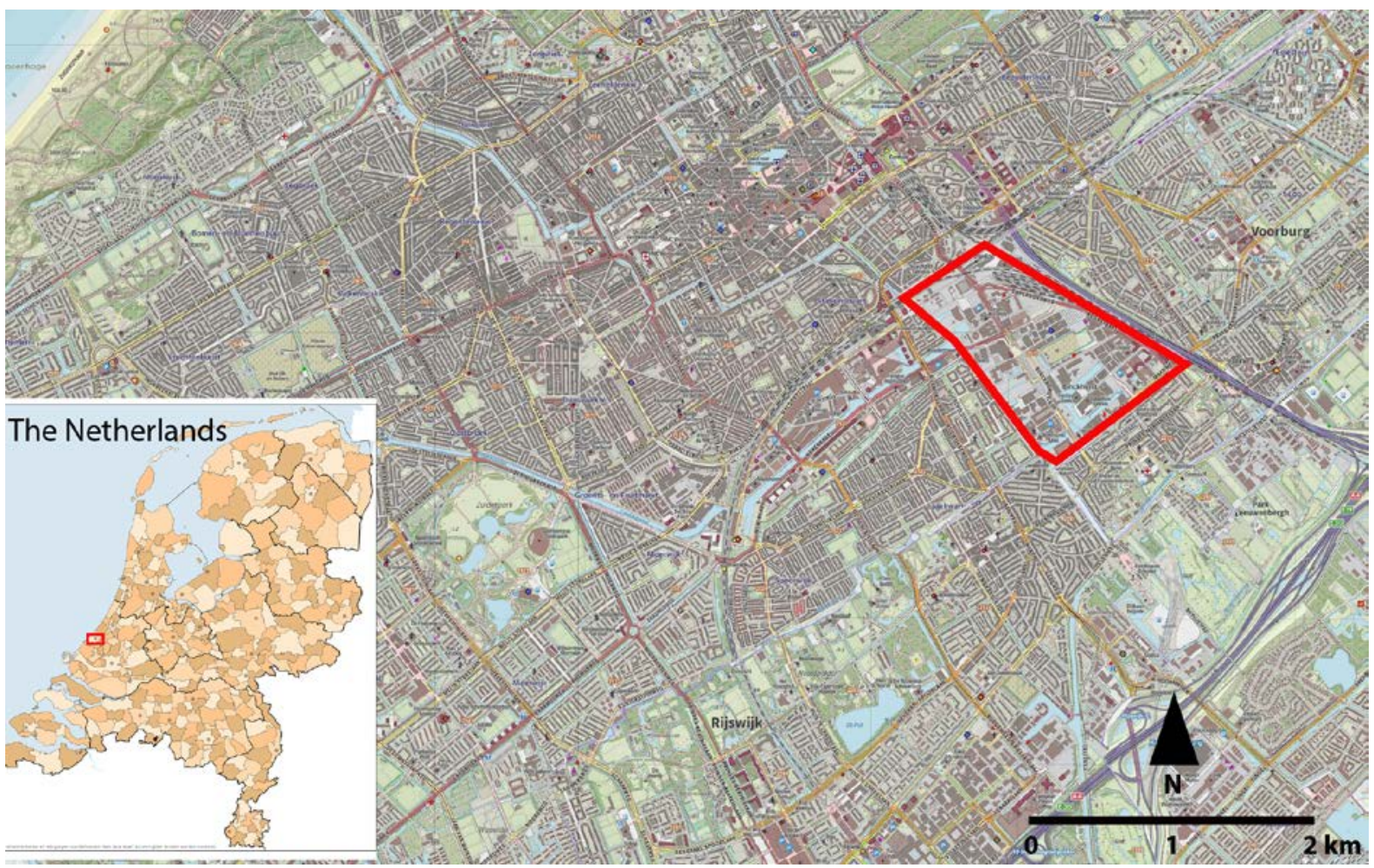

Figure 2: Map of the industrial Binckhorst area within The Hague (Open Geodata, Creative Commons CC-BY)

Today, the Binckhorst is the only industrial area within the city. The Hague has for historical reasons always been a political and service oriented urban economy (e.g. national government, residence of the King of The Netherlands, International Court of Justice) (Meijers, et al., 2014). Today, however, also the industrial future of the Binckhorst is under pressure. Going back to the beginning of the 21st century, municipality visions and plans exist of retransforming The Binckhorst into a high-end urban residential and commercial area. These transformation plans, however, were cancelled as a consequence of the financial and economic crisis of 2008. After the crisis, from 2016 onwards, the ideas to transform The Binckhorst resurfaced. The Netherlands, and in particular its biggest cities such as The Hague, are currently experiencing a housing shortage (PBL, 2018). For The Hague in particular, the challenge is significant because space is scarce and a growth of somewhere between 50.000 to 100.000 new inhabitants is foreseen, a 10-20\% increase. The challenge and the lack of space, explains partly why the municipality of The Hague has assigned The Binckhorst, an area almost without any inhabitants, as the most important area where via retransformation of existing industrial and commercial areas the housing task should take place.

In comparison with the pre-crisis plans, the most recent development plans do not state anymore that the whole area has become a high-end urban area. The current plans steer towards a mixed living-working area. The reason behind this is that during the crisis, a strong bottom-up network of existing actors (residents, organisations, companies) was created, namely 'I'm Binck', influencing the municipal policy making. One of their agenda points is to steer the current and future Binckhorst activities towards the CE (I'm Binck, 2019). 
This CE ambition fits well with the ambitions of The Hague. Indeed, in line with the Dutch government (Nederlandse Overheid, 2016), also The Hague has committed itself to become fully circular in 2050 (City of The Hague, 2018). Hence, in the most recent plan for The Binckhorst it is stated: "The Binckhorst is promising regarding the $\mathrm{CE}$ because it host already many circular functioning activities, from creative start-ups to full-grown companies" (City of The Hague, 2018, p.41). Next to 'I'm Binck', the potential of CE has been put forward by on the one hand the residential and commercial project developers (cf. We Think Binck, 2019), and on the other hand the existing companies (BLF, 2019).

More recently, however, the ambition for a mixed area development, has created a conflict between the existing industrial functions and the new to come residential and commercial functions (BLF, 2019). Striving for such mixed area (re)development is, namely, not straightforward. For example, the existing jurisdictional environmental buffers around the existing heavy industrial functions, prevent for a large part of the construction of residential functions within The Binckhorst. Taking these buffers into account among other constraints (e.g. logistics), many of the foreseen residential developments (between 5.000 to 20.000 housing units, cf. City of The Hague, 2018) are difficult to achieve (Anteagroup, 2018). To overcome these environmental jurisdictional constraints, the municipality of The Hague has categorised the (re)development plan of The Binckhorst under the Dutch Crisis- and Repair law, a law put into force during the crisis to encourage development and economic activities (BZK, 2019). Without going into detail, the rationale of the Crisis- and Repair Law is to encourage development by making it possible to allow more "flexibility" with existing regulations (Barkhuysen \& Kortmann, 2010). Hence, by categorising the current development plan of The Binckhorst under this law, also jurisdictionally it is possible to strive towards a mixed working/living area.

The reason why The Binckhorst plan creates a conflict between the existing industrial functions and the future residential functions, is because of lack of clarity on how far one may overstep existing environmental constraints. In particular, the discussion centres around the existing asphalt and concrete factories, located within the centre of The Binckhorst. Both functions are categorised within the so-called 'high environmental impact category' (Hoge Milieucategorie, HMC), which implies that around the functions within a buffer between 400 and 500 meter no residential functions may be build (Bouwcampus, 2018; lenW, 2019). This buffer is, however, not straightforward. There is namely a difference between the allowed environmental circle that is part of the permit, and the actual environmental circle. This difference exists because when the permit is given to companies, this allows them to expand their business, and thus an increase of noise and smell, if necessary. Under the Crisis- and Repair Law, currently it is not clear how if development plans have to take into account the allowed environmental circle, or the actual environmental circle, and if the latter is the case, how then compensation is arranged (see in this respect Boeve, 2017).

The outcome of this discussion on The Binckhorst development plan is not yet known and part of ongoing appeals at the Dutch Council of State (City of The Hague, 2019). The main argument here, also regarding preceding legal debates in other area (re)developments in The Netherlands (cf. Boeve, 2017), is that the existing industrial actors are not keen to lose their allowed environmental circle because this would prevent them to expand in the future, both in space, but also in terms of an increase of activities within the existing factory, which creates more mobility, sounds and/or smells. In particular for The Binckhorst, the reason why the existing companies don't want to lose their allowed environmental circle, is because of their CE ambitions. Indeed, the industrial actors have signaled that if they want to become circular in their activities, contributing thus to the sectoral and governmental circular ambitions (RWS, 2019), there will be an increase of (temporarily) nuisance, regarding the increase of noise, smell, space and logistics.

This functional (area) circular ambition conflicts with the design (area) circular ambition of the municipality. Indeed, it is apparent that The Hague advertises their plans for the Binckhorst area by using among others, circularity. Circularity here is understood to make the (future) built environment circular, while not taking into account how, where and by who this will be done. Even if not the current asphalt and concrete functions within the Binckhorst would also contribute to the circular functioning of the circular built agenda of the Binckhorst, this is an example of problem displacement (North, 2010).

\section{Amsterdam and its region - conflicting circular economy and urban development agendas}

Amsterdam has been undergoing a process of rapid gentrification and urban expansion driven by a shift towards service economy, migration, development of public transport network (Savini et al., 2016). The city's population in 
2000 was 734,594, while in 2018 it reached 862,965¹. From 2000s onwards the expansion of Amsterdam's urban fabric has been increasingly focusing on the port areas, leading to tension with the proponents of maintaining port activities in the vicinity of the city (Savini et al., 2015).

The Amsterdam's CE strategy positions the city as a frontrunner in this field with the aim to become fully circular by 2050 (Gemeente Amsterdam, 2015, 2019). Given that the construction sector creates 40\% of total municipal waste in Amsterdam, closing material flow loops in construction and demolition waste has been chosen as one of the priorities for this strategy.

We mapped the construction and demolition waste in the Amsterdam Metropolitan Area using the flow mapping tool of the Geodesign Decision Support Environment or GDSE (Arciniegas et al., 2019), developed as part of the Horizon2020 project REPAiR (REPAiR, 2017a, 2017b). The map of construction and demolition waste flows produced using that method (fig. 3) shows all activities related to construction and demolition waste flow that can be labelled as circular. These processes include activities such as recycling, recovery, or storage, etc.

What is evident from that map is that the metabolic flows extend far beyond the administrative boundaries of Amsterdam or its metropolitan area, reaching out to Rotterdam, Utrecht, the Province of Gelderland or even as far as Germany. Thus, the scale of the system of metabolic flows in this sector is by no means local or even regional, but national. This in turn, entails substantial emissions of $\mathrm{CO} 2$ from transporting construction and demolition waste across those relatively large distances.

${ }^{1}$ https://opendata.cbs.nl/ 


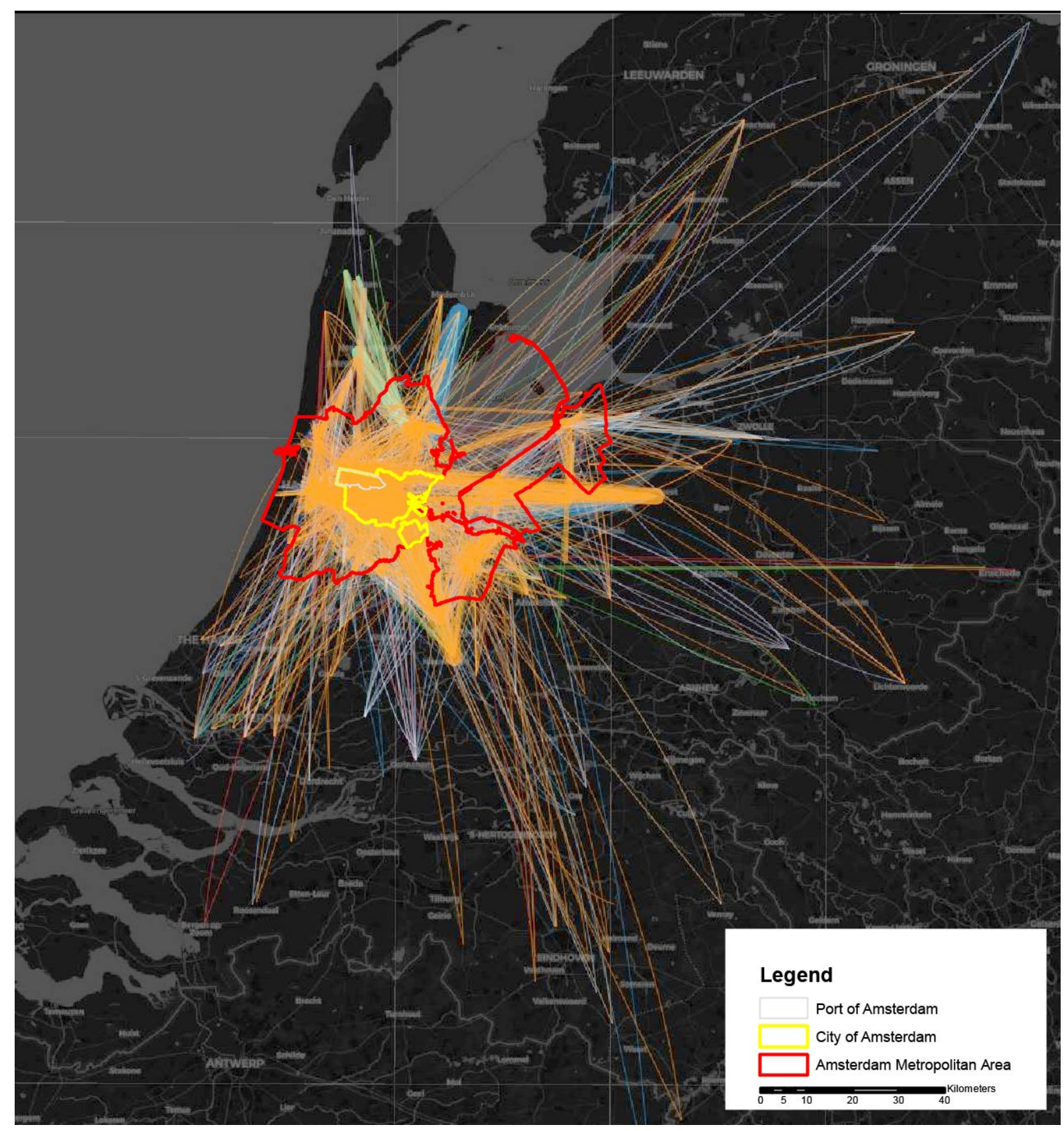

Figure 3: Circular flows in Amsterdam region: construction and demolition waste (REPAiR, 2017a)

Mapping flows of construction and demolition waste allows not only to grasp the geographical sprawl of the network of actors involved in the production and processing of this type of waste. It also makes it possible to identify clusters of circular activities. Using the GDSE tool we visualised the number of companies involved in the circular activities by location on the scales from the region down to the neighbourhood. As figure 4 below shows, activities in processing of construction and demolition waste tend to be clustered in the West of Amsterdam. 


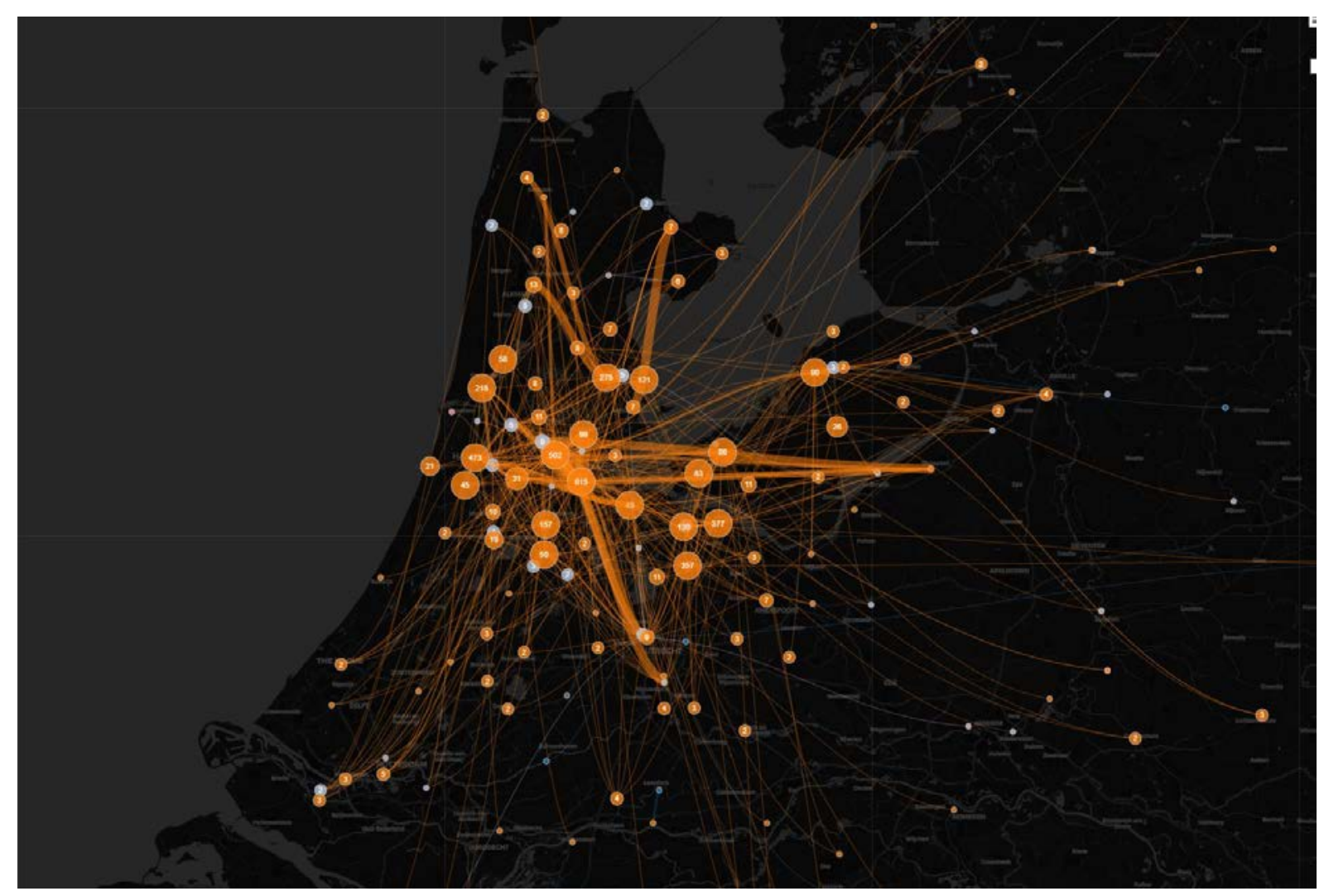

Figure 4: Clusters of companies engaged in circular activities based on construction and demolition waste flow in the Amsterdam region (REPAiR, 2017a)

This part of the city is the main industrial area of the region of Amsterdam and the location of the Port of Amsterdam, with many companies dealing with construction and demolition products and processing as well as a plethora of firms from the steel industry, petrochemical industry as well as waste management sector (from the largest companies like the AEB, the municipal waste company, or SUEZ and Renewi, to smaller scale companies involved in recycling and waste management). The existing circular activities, therefore, are linked to the established industrial actors operating in the port area (cf. relatedness). These current industrial activities provide most of the Amsterdam's already existing 'core' circular jobs (cf. Burger et al., 2019) related to extending the life of products (maintenance, refurbishment) or transformation of waste into resources (Circle Economy \& HERO, 2019).

Our analysis of material flows shows the importance of the port area in the Amsterdam region. Figure 5 below indicates the magnitude of the construction and demolition waste flows in and out of the port area only (Westpoort neighbourhood), underscoring the central role played by the port for construction and demolition waste flows and related recycling and reuse activities. 


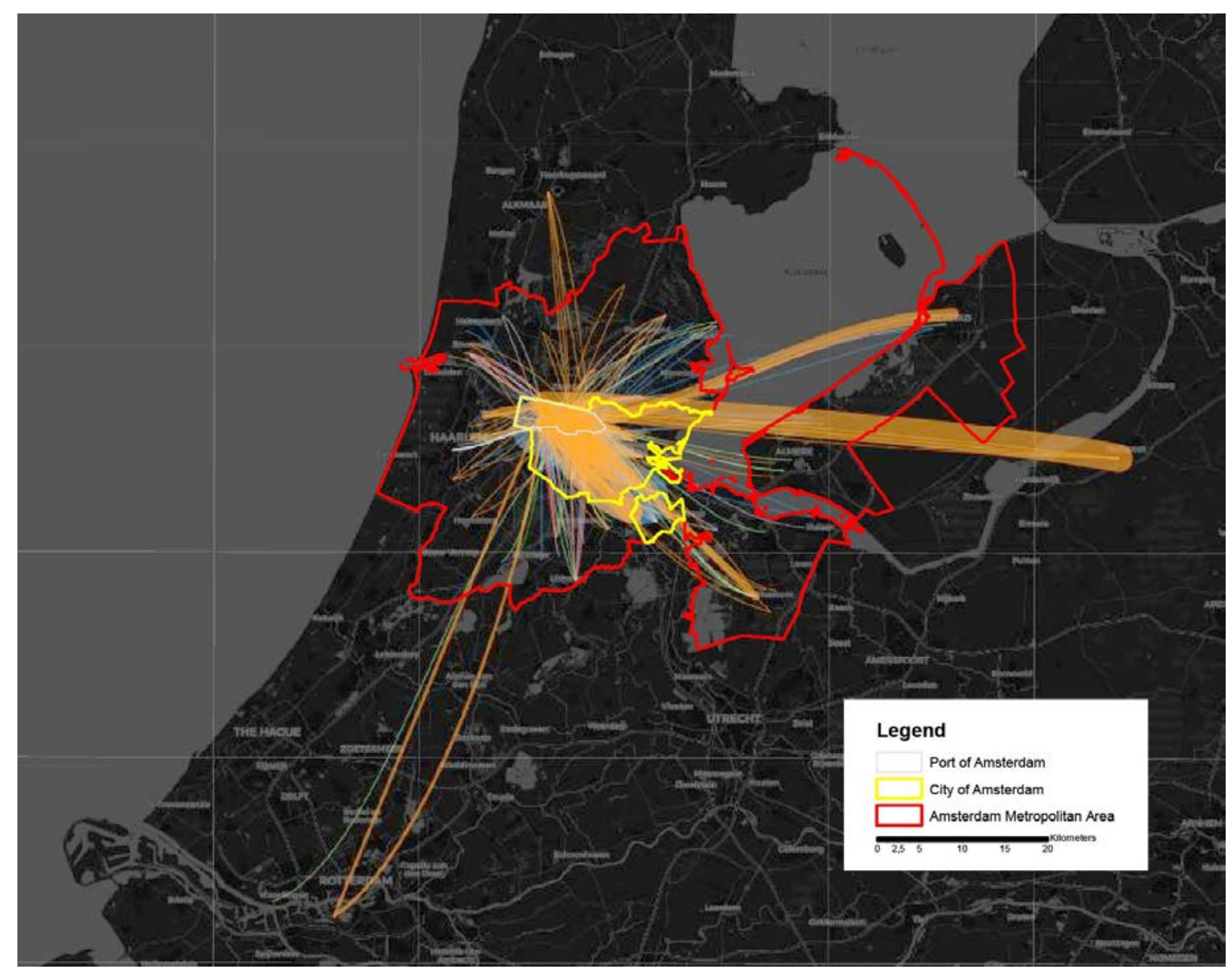

Figure 5: Flows of construction and demolition waste (REPAiR, 2017a)

\section{Tensions and paradoxes}

Our first case study, The Hague - Binckhorst forms a clear example how from almost the plot level, different circular 'versions', between circular area design and circular area functioning, can conflict. The unclearness of how the circular functions (cf. the asphalt and concrete factories) will contribute to the CE today and especially to the CE of tomorrow, explains why the (potential) importance is not known and acknowledged.

In Amsterdam, our second case study, we showed what the potential implications are of the existing system of metabolic flows for local spatial planning. To our knowledge, at least based on the circular discourse, a concrete land use conflict has not occurred in Amsterdam. However, we think that the chance that this will occur is apparent. to cope with the increase of inhabitants, the municipality has namely raised its wishes to redevelop an industrial port area closest located to the city into a residential area, nicknamed Haven-Stad (cf. Port City). The plans for the development of Haven-Stad, a new urban district in the former port terrain, entails construction of 40.000-70.000 homes with very ambitious sustainability and circularity goals: 75\% reduction in CO2 emissions, emission-free mobility, rainproof neighbourhoods, 50\% reuse of resources and $65 \%$ waste separation (Gemeente Amsterdam, 2017). To align with the circular ambitions, Haven-Stad is foreseen to be an area where circular construction solutions, with modular and adaptable buildings, and circular development of infrastructure and public space will pioneer. This is to be facilitated by flexible zoning to allow for experimentation with circular construction and the use of circular tendering for public buildings, infrastructure and public space development (Gemeente Amsterdam, 2019).

The Amsterdam policy visions and plans, however, not clearly indicate how such development will be build in a circular way, thus during the construction, as well how it will function in a circular way, once it is populated. Hence, the question can be named, where are the crucial core activities, existing or innovative, that will not only make the economy circular, but also as close as possible. Arguably, this is today already apparent. Indeed, the 
mapping of the current system of metabolic flows, already shows that the CE is by no means local or even regional, but (inter)national.

Our analysis shows that, although the current system of metabolic flows is beyond the local, of importance are the existing clustered circular activities within the port of Amsterdam. Arguably, if the port of Amsterdam, and its dedicated infrastructure, would not be located in Amsterdam or closely by, it is safe to argue that the system of metabolic flows would even have a larger extent as it has today.

The municipality recognises the growing CE cluster in the port as an asset for realising these ambitions (Gemeente Amsterdam, 2017). Also the Port Authority Amsterdam increasingly positions the port of Amsterdam as a circular hub. Illustrative is that it recently changed its name from 'the port of Amsterdam' to 'the port for Amsterdam', all to highlight its importance for the circular functioning of the city and area. The Port Authority of Amsterdam labelled the whole west part of the region of Amsterdam, as the 'circular West Axis', an area supposed to be the region's driver of transition towards circular economy stretching from the port, via the Schiphol airport and business park, to the so-called Greenport of Aalsmeer, where the horticultural industry is clustered. This West Axis is seen as the place where related and unrelated innovation can foster in the transition towards a fully CE (Metropoolregio Amsterdam, 2017).

Arguably these ambitions are straightforward and do align with the literature calling to connect the ecological, social and economic. Indeed, from a geographical point of view, the West Axis has all the potential to enable existing circular activities to develop further, to connect to related and unrelated economic sectors and to find the proper location to do so (e.g. factory to offices). Indeed, the circular activities related to construction and demolition waste valorisation (but also to processing other material flows already related to the industries in the port of Amsterdam, for instance organic or plastic waste) require industrial spaces and can hardly take place in the vicinity of residential areas due to externalities they produce, such as noise or odour. This is in contrast with those activities related to rather new 'enabling' circular jobs based on knowledge development and circular product or process design, which tend to cluster not in the industrial area but rather in the centre of Amsterdam, Zuidas business park or around Schiphol Airport (Circle Economy \& HERO, 2019).

In other words, the new knowledge-based kinds of circular activities, unlike the 'core' circular activities related to existing industrial actors, do not require buffer zones to offset negative externalities and blend well with dense urban environments. The transition towards circular economy has the potential to promote synergies between these two kinds of activities: the 'core' industrial circular activities related to the businesses already present in the industrial area in the port (related diversification); and the new 'enabling' activities related to design, networking and knowledge production (unrelated diversification) emerging in the Amsterdam's centre and business parks. That said, harnessing those synergies to promote (re)emerging circular industries through a combination of related and unrelated diversification of the city's economy depends on its ability to recognise and cater to the (conflicting) spatial needs of both of these types of circular economy actors.

The irony is thus, that, although it supports the West Axis on a regional scale, on the connection between this regional scale and the more local scale the City of Amsterdam's urban development plans would undermine the role of the port for circular economy by displacing the industry away from the city. In other words, even if the problem displacement in the best way occurs only from the now closest port area to one further away, it will entail that the extent of the system of metabolic flows will increase. Moreover, this system today is already extended and should be internalized more to decrease the extent. Otherwise put, Haven-Stad, although labelled as a circular area, will thus most likely further increase the geographical system of metabolic flows, but also be a missed opportunity to capitalise on the potential connections of the existing industrial actors in the port to circular business models and harm the re-emergence of a CE cluster in Amsterdam with materials loops being closed in the vicinity of the city.

\section{Discussion and conclusion}

This paper sets out to explore the importance of space for the transition towards CE. We first showed that in current CE literature, the predominant focus is on connecting metabolic flows and on circular innovation, but there is hardly any discussion on the consequences of this, on the role of locations, and on how this can lead to problem displacement. We explained that problem displacement not only has ecological consequences, but also potentially constrains the CE as a re-emerging industry. The locational and path dependent elements that enable circular innovation should be underlined. 
As we showed, in The Hague and Amsterdam, industrial areas are increasingly redeveloped into commercial or residential areas. There may be reasons for this, like housing shortage, but it is apparent that these redevelopment plans are based on ambitions to become circular, bot in terms of activities taking place in those redeveloped areas and in the process of redevelopment (circular construction techniques to be used, circular tendering, etc.). This is paradoxical, because (potential) area industrial, office or residential functions will constitute the CE of the future. Although all of these functions are indeed necessary to enact the transition towards CE, the plans for redevelopment of the industrial areas of The Hague and Amsterdam put an emphasis on office and residential uses of land, displacing the industrial activities. This illustrates the confusion between the circular discourse used and the actual urban planning decisions, leading to problem displacement. Indeed, the circular residential redevelopment of Binckhorst or Haven-Stad is only possible if other areas and the industrial functions located in those areas, contribute to the short- and long-term development of the system of metabolic flows of those and other residential areas, which requires industrial spaces and produces externalities which clash with residential and office land use. Therefore, one can question the circular ambitions of The Hague and Amsterdam, by studying how the system of metabolic flows already today crosses beyond their borders and how other regions constitute and contribute to their circular economic activities. Thus, the ongoing residential and office redevelopment plans of both cities requiring externalising circular activities - such as recycling, remanufacturing or extraction of resources from waste material - undermine the future CE of both cities, even if these developments are trumpeted as 'circular'.

We introduced the concept of re-emerging industries to first acknowledge the role of existing industrial functions and their locations for the system of metabolic flows of today, and second, their role during the transition of the CE. Our framework offers a lens to further our understanding of the so far neglected geographical dimension of CE. Cities do - and always have - relied on flows to and from the areas outside their borders and are not isolated (cf. Wachsmuth, 2012). Thus it is a utopia to push for a CE based on 'radical' localism (cf. North, 2010). This, however, does not mean that cities or regions can continue externalizing circular activities. Instead, city leaders and planners have to be aware, first, of the extent of their 'metabolic sprawl', and second, of how the existing (related) circular activities can be maintained and developed improved. This entails that today, in prospect of the future CE, one should consider protecting the existing industrial activities engaged in the R-strategies within or close to the boundaries of an urban region, recognising that they are important already today in the early stages of development of $\mathrm{CE}$, but also that they provide a crucial basis for development of CE in the future.

Therefore, policy makers, and especially spatial planners, at the city or regional scale should consider more seriously the implications of the transition towards CE in order to best exploit its transformative potential and use it as a driver for revitalising existing industries and creating new connections to the emerging knowledge-based circular activities. Simply said, we cannot ignore any longer the negative externalities of CE activities and the potential conflict for space between CE industries and the expanding residential urban areas. Moreover, if innovation is derived from specialisation built up in the past, and the connection with related and unrelated activities, the importance of circular industrial functions, especially those closely located, become increasingly important (Burger et al., 2019).

The limitation of our research is that it focuses on an early stage of transition towards CE, when the spatial conflicts we shed light on are still nascent or will unfold in the future. That said, if some of our conclusions remain hypothetical, they do point to important consequences for the transition towards CE in the future and its relation to urban expansion and redevelopment. Coping with these (future) conflicts, however, invites a degree of caution because $C E$ is as of now still emerging and it will take decades to close the material flows in a region, which echoes the points raised by Hassink et al. (2019, p.1638). Hence, future research should explore in more detail these spatial conflicts and paradoxes of CE to understand why today there is already a metabolic sprawl, what drives this, and what this implies for exploring the potential of CE to drive innovation and stimulate regional economies by connecting the related and unrelated diversification strategies.

Funding: Karel Van den Berghe was funded by the expertise center Accelerating the Circular Economy in ZuidHolland (ACCEZ) of the Dutch province of South-Holland (grant number PZH-2018-658193468).

Acknowledgements: The empirical material on the case of Amsterdam builds on the REPAiR project, which has received funding from the European Union's Horizon 2020 research and innovation programme under grant agreement No 688920. The Authors would like to acknowledge the work of the REPAiR project team on the GDSE and on the material flow analysis for Amsterdam cited in this paper, including: Gustavo Arciniegas, Rusnè Šileryté, Balázs Dukai, Christoph Franke, Max Bohnet, Jens-Martin Gutsche, Bob Geldermans and others. 
Conflicts of Interest: The authors declare no conflict of interest.

\section{References}

Albers, E., \& Benjamins, M. (2012). De Binckhorst: bedrijventerrein in beweging. The Hague: Nieuwe Haagsche BV.

Anteagroup (2018). Omgevingsplan Binckhorst. Aanvulling Omgeving Effect Rapport.

Arciniegas, G., Šileryté, R., Dąbrowski, M., Wandl, A., Dukai, B., Bohnet, M., \& Gutsche, J. M. (2019). A geodesign decision support environment for integrating management of resource flows in spatial planning. Urban Planning, 4(3), 32. doi: 10.17645/up.v4i3.2173

Barkhuysen, T., \& Kortmann, C. (2010). Versnelling van infrastructurele en bouwprojecten: de crisis- en herstelwet voorbij? Ars Aequi, 5.s

Bathelt, H., \& Glückler, J. (2003). Toward a relational economic geography. Journal of economic geography, 3(2), 117-144. doi:10.1093/jeg/3.2.117

BLF (2019). Bedrijvenvereniging Binckhorst Laakweg Fruitweg. Retrieved from http://www.bedrijvenverenigingblf.nl/

Boeve, M. (2017). Het omgevingsrecht van de compacte stad: Het omgevingsrechtelijk instrumentarium voor verdichting en functiemenging in het stedelijk gebied. (PhD), University of Amsterdam, Amsterdam.

Boschma, R., \& Frenken, K. (2006). Why is economic geography not an evolutionary science? Towards an evolutionary economic geography. Journal of economic geography, 6(3), 273-302.

Bouwcampus (2018). Wonen naast HMC bedrijven, een kansrijke combinatie.

Bureau van Dijk (2017) - ORBIS database. Amsterdam: Bureau van Dijk. https://www.bvdinfo.com/en-gb/ourproducts/data/international/orbis

Burger, M., Stavropoulos, S., Ramkumar, S., Dufourmont, J., \& van Oort, F. (2019). The heterogeneous skillbase of circular economy employment. Research Policy, 48(1), 248-261. doi:https://doi.org/10.1016/j.respol.2018.08.015

BZK. (2019). Praktijkervaringen Crisis- en herstelwet. Voortgangsrapportage 2017-2018.

Circle Economy \& HERO (2019) Circular Economy and Skills in the Amsterdam Metropolitan Area. https://www.circle-economy.com/wp-content/uploads/2018/12/Final-Circular-Jobs-and-Skills-in-theAmsterdam-Metropolitan-Area.pdf

City of The Hague. (2018). Circulair Den Haag. Transitie naar een duurzame economie. Retrieved from https://denhaag.raadsinformatie.nl/document/6291317/1/RIS299353_Bijlage_1

City of The Hague (2019). Binckhorst - Inwerkingtreding - Omgevingsplan. Retrieved from https://www.denhaag.nl/nl/in-de-stad/wonen-en-bouwen/bestemmingsplannen/binckhorstinwerkingtreding-omgevingsplan.htm

COM. (2019). Communication on The European Green Deal. Retrieved from Brussels: https://ec.europa.eu/info/strategy/priorities-2019-2024/european-green-deal_en

Directive 2008/98/EC of the European Parliament and of the Council of 19 November 2008 on waste and repealing certain Directives.

Frenken, K., Van Oort, F., and Verburg, T. 2007. Related variety, unrelated variety and regional economic growth. Regional Studies 41: 685-97

Gemeente Amsterdam (2015). Amsterdam Circulair. Een visie en routekaart voor de stad en regio.

Gemeente Amsterdam (2017) Concept ontwikkelstrategie Haven-Stad: Transformatie van 12 deelgebieden. Amsterdam: Gemeente Amsterdam. https://www.amsterdam.nl/projecten/haven-stad/ ontwikkelstrategie/

Gemeente Amsterdam (2019) Building Blocks for the New Strategy Amsterdam Circular 2020-2025. Directions for a thriving city within planetary boundaries. Amsterdam: Gemeente Amsterdam. https://www.circleeconomy.com/wp-content/uploads/2019/06/Building-blocks-Amsterdam-Circular-2019.pdf

Gibbs, D. (2018). Sustainable regions. In A. Paasi, J. Harrison, \& M. Jones (Eds.), Handbook on the Geographies of Regions and Territories: Edward Elgar Publishing, Incorporated.

Ghisellini, P., Cialani, C., \& Ulgiati, S. (2016). A review on circular economy: the expected transition to a balanced interplay of environmental and economic systems. Journal of Cleaner Production, 114, 11-32. doi:https://doi.org/10.1016/j.jclepro.2015.09.007

Harrison, J., Delgado, M., Derudder, B., Anguelovski, I., Montero, S., Bailey, D., \& De Propris, L. (2019). Pushing regional studies beyond its borders. Regional Studies, 1-11. doi:10.1080/00343404.2019.1672146

Hassink, R., Isaksen, A. and Trippl, M. (2019) Towards a comprehensive understanding of new regional industrial path development, Regional Studies, 53:11, 1636-1645, DOI: 10.1080/00343404.2019.1566704

IenW. (2019). Bedrijven en milieuzonering. Retrieved from https://www.infomil.nl/onderwerpen/ruimte/functies/bedrijven/milieuzonering/ 
I'm Binck. (2019). Platform voor ondernemingen Binckhorst. Retrieved from https://imbinck.nl/

Korhonen, J., Nuur, C., Feldmann, A., \& Birkie, S. E. (2018). Circular economy as an essentially contested concept. Journal of Cleaner Production, 175, 544-552. doi:https://doi.org/10.1016/j.jclepro.2017.12.111

Meijers, E., Hoogerbrugge, M., Louw, E., Priemus, H., \& Spaans, M. (2014). City profile: The Hague. Cities, 41(Part A), 92-100. doi:https://doi.org/10.1016/j.cities.2014.05.012

Metropoolregio Amsterdam (2017). Ontwikkelplan Circulaire Economie Metropoolregio Amsterdam. Amsterdam: Metropoolregio Amsterdam. https://www.amsterdameconomicboard.com/app/uploads/2018/04/Ontwikkelplan-Circulaire-EconomieMRA.pdf

Murray, A., Skene, K., \& Haynes, K. (2017). The Circular Economy: An Interdisciplinary Exploration of the Concept and Application in a Global Context. Journal of Business Ethics, 140(3), 369-380. doi:10.1007/s10551-015-2693-2

Nederlandse Overheid (2016). A circular economy in the Netherlands by 2050: Government-wide programme for a circular economy. The Hague: Ministry of Infrastructure and the Environment and Ministry of Economic Affairs.

Neffke F., Henning M., and Boschma, R. (2011). How do regions diversify over time? Industry relatedness and the development of new growth paths in regions. Economic Geography, 87, 237- 265. doi:10.1111/j.19448287.2011.01121.x

North, P. (2010). Eco-localisation as a progressive response to peak oil and climate change - A sympathetic critique. Geoforum, 41(4), 585-594. doi:https://doi.org/10.1016/j.geoforum.2009.04.013

OECD. (2019). Business Models for the Circular Economy. Opportunities and Challenges from a Policy Perspective.

Paasi, A. (2010). Commentary. Environment and Planning A, 42(10), 2296-2301. doi:10.1068/a42232

PBL. (2018). Oplopend woningtekort in stedelijke regio's.

PBL. (2019). Outline of the Circular Economy.

Reike, D., Vermeulen, W. J. V., \& Witjes, S. (2018). The circular economy: New or Refurbished as CE 3.0? Exploring Controversies in the Conceptualization of the Circular Economy through a Focus on History and Resource Value Retention Options. Resources, Conservation and Recycling, 135, 246-264. doi:https://doi.org/10.1016/j.resconrec.2017.08.027

REPAiR (2017a). REsource Management in Peri-urban AReas: Going Beyond Urban Metabolism. D3.1 Introduction to methodology for integrated spatial, material flow and social analyses. Delft: Delft University of Technology. http://h2020repair.eu/wpcontent/uploads/2018/03/Deliverable_3.1_Introduction_to_methodology.pdf

REPAiR (2017b). REsource Management in Peri-urban AReas: Going Beyond Urban Metabolism. D3.3 Process model for the two pilot cases:Amsterdam, the Netherlands \& Naples, Italy. Delft: Delft University of Technology. http://h2020repair.eu/wp-content/uploads/2019/11/Deliverable-3.3-Process-model-for-thetwo-pilot-cases-Amsterdam-the-Netherlands-and-Naples-Italy-final.pdf

Rijkswaterstaat (2019). Landelijk Meldpunt Afvalstoffen. Den Haag: Rijkswaterstaat. https://www.Ima.nl/

RWS. (2019). Afvalstromen en ketens. Retrieved from https://www.afvalcirculair.nl/onderwerpen/afvalstromenketens/

Savini, F., Boterman, W. R., Van Gent, W. P., \& Majoor, S. (2016). Amsterdam in the 21st century: Geography, housing, spatial development and politics. Cities, 52, 103-113.

Stake, R. E. (1995). The Art of Case Study Research: SAGE Publications.

Storper, M. (1997). The regional world: territorial development in a global economy. New York : Guilford Press.

Su, B., Heshmati, A., Geng, Y., \& Yu, X. (2013). A review of the circular economy in China: moving from rhetoric to implementation. Journal of Cleaner Production, 42, 215-227. doi:https://doi.org/10.1016/j.jclepro.2012.11.020

Swyngedouw, E. (2006). Metabolic Urbanization: The Making of Cyborg Cities. In N. Heynen, M. Kaika, \& E. Swyngedouw (Eds.), In the Nature of Cities (pp. 21-40): Taylor \& Francis.

Tanner, A. N. (2014). Regional branching reconsidered: Emergence of the fuel cell industry in European regions. Economic Geography, 90, 403-427. doi:10.1111/ecge.12055

UN. (2018). Circular Economy: the new normal?

Van den Berghe, K., \& Vos, M. (2019). Circular Area Design or Circular Area Functioning? A DiscourseInstitutional Analysis of Circular Area Developments in Amsterdam and Utrecht, The Netherlands (20711050). Retrieved from https://www.mdpi.com/2071-1050/11/18/4875

Van den Berghe, K., Jacobs, W., \& Boelens, L. (2018). The relational geometry of the port-city interface: Case studies of Amsterdam, the Netherlands, and Ghent, Belgium. Journal of Transport Geography, 70(C), 5563. doi:https://doi.org/10.1016/j.jtrangeo.2018.05.013 
Van Ewijk, S., \& Stegemann, J. A. (2016). Limitations of the waste hierarchy for achieving absolute reductions in material throughput. Journal of Cleaner Production, 132, 122-128.

Varró, K., \& Lagendijk, A. (2013). Conceptualizing the Region - In What Sense Relational? Regional Studies, 47(1), 18-28. doi:10.1080/00343404.2011.602334

Wachsmuth, D. (2012). Three Ecologies: Urban Metabolism and the Society-Nature Opposition. The Sociological Quarterly, 53(4), 506-523. doi:10.1111/j.1533-8525.2012.01247.x

We Think Binck. (2019). Manifesto Binckhorst. Retrieved from https://wethinkbinck.nl/

Wolman, A. (1965). The Metabolism of Cities. Scientific American, 213(3), 178-193.

Yeung, H. W.-c. (2005). Rethinking relational economic geography. Transactions of the Institute of British Geographers, 30(1), 37-51. doi:10.1111/j.1475-5661.2005.00150.x 